\title{
Women's Right To Land Ownership In Swat State Areas The Swat State Era And The Post-State Scenario
}

\author{
Sultan-i-Rome \\ Department of History \\ Government College Matta, Swat, Pakistan
}

\begin{abstract}
This paper presents a study of riwaj (customary law) in the traditional society of the present-day Provincially Administered Tribal Areas (PATA) of the North-West Frontier Province, Pakistan. Under riwaj only males could own land; women had no right to inherit land. During the Swat State era (1915-1969), on the whole, the traditional practice remained the law of inheritance and ownership of land under which the women folk were not entitled to inherit. However, during the reign of Miangul Jahanzeb in some cases the women were given the right to inherit and own land. The pattern of land ownership remained the same, in general, after the merger of the state in 1969. In this scenario, The West Pakistan Muslim Personal Law (Shariat) Application Act, 1962 (W. P. Act V of 1962), with exception to the proviso of section 3 and 7, was extended to the area on 15 January 1976. Although extension of The West Pakistan Muslim Personal Law (Shariat) Application Act, 1962, brought no practical change for the time being, its extension along with the land settlement carried out by the provincial revenue department, in most of the study area, were destined to bring the required change.
\end{abstract}

\section{تلفيص المقاله}

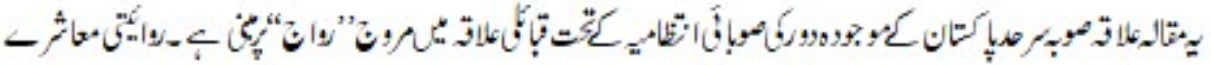

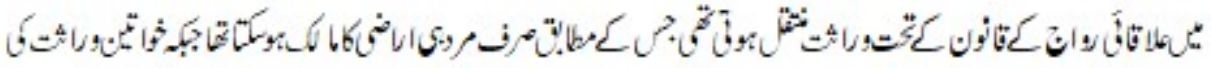

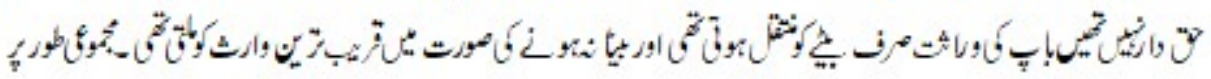

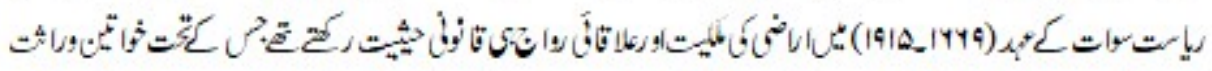

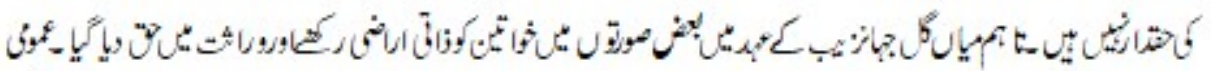

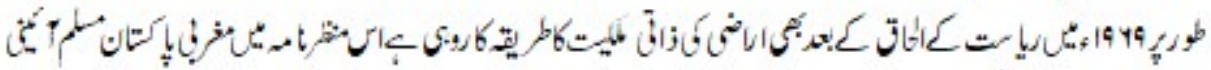

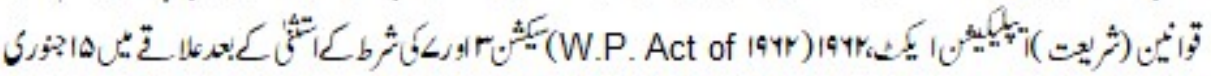

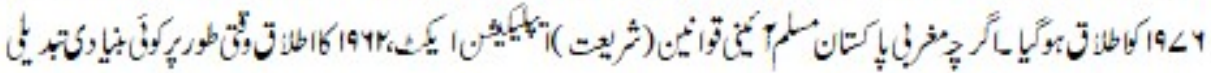

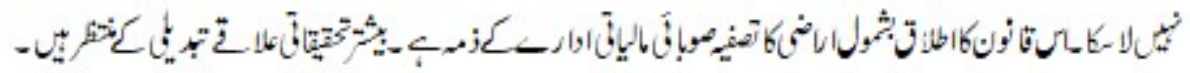




\section{Introduction}

The historic Swat valley is situated in the present-day North-West Frontier Province of Pakistan and is part of the Provincially Administered Tribal Areas (PATA). It lies between $34^{0}-40^{\prime}$ to $35^{0}$ north latitude and $72^{0}$ to $74^{0}-6^{\prime}$ east longitude (Imperial Gazetteer of India, 1991).

Traditionally Swat valley was divided into two distinct tracts: Swat Kohistan - mountain country on the upper reaches of the Swat River and its tributaries as far south as Ainand Swat proper. Swat proper was subdivided into Bar (upper) and Kuz (lower) Swat. The first one extends from Ain to Landakay (commonly written as Landakai) while the latter from Landakay to Kalangai, a few miles above the junction of the Swat and Panjkora rivers. The Swat Kohistan too has two parts namely Gawri (also written as Garwi/Garvi and commonly referred to in the official writings as Kalam) and Torwali tracts.

For most of its known history Swat retained its separate entity. It remained cradle of a civilisation and witnessed being invaded by formidable armies. In sixteenth century $\mathrm{CE}$ the Yusufzai Afghans occupied the land and most of its inhabitants were pushed to the left bank Indus region of Hazara. Although the Yusufzais did not make their advance towards the mountainous area of Swat Kohistan they continued their inroads in other bordering areas and extended their occupation also to the territories of the present-day Buner and Shangla districts areas.

The Yusufzais occupied Swat and emerged and remained dominant segment but did not establish a state and government, and lived in the tribal fashion divided into two opposite blocks called dalas (singular dala). The English occupation of Peshawar and the plain areas up to the border of Swat, with the annexation of Punjab in 1849, alarmed the Swat Yusufzais, however. With the view to retain their independence, they installed Sayyad Akbar Shah of Sithana as their king who ruled till his death in 1857. With his death Swat was deprived of a ruler.

In 1879 the neighbouring Khan of Dir occupied some territories lying on the right-bank of the Swat River and by the end of 1881 the entire right-bank proper Swat valley virtually came under his rule. Weary of the constant internal faction fighting and excesses of the agents of the Nawab of Dir, the people of some cantons of the right-bank Swat made a common cause and defeated Dir's forces in various encounters. A jarga ${ }^{1}$ (commonly, erroneously, spelled as jirga) of the concerned clans at last installed Abdul Jabbar Shah as king of Swat in April 1915. He evolved rudimentary administrative machinery and expanded the State to some extent but the jargah broke relations with him in September 1917 and asked him to leave Swat. ${ }^{2}$ 
With the removal of Abdul Jabbar Shah, the jargah members offered the seat to Miangul Abdul Wadud, ${ }^{3}$ grandson of Abdul Ghafur ${ }^{4}$ alias Saidu Baba and the turban of kingship was wounded round his head. With the coming of Abdul Wadud into power, expansion, consolidation and development of Swat State began in real sense. Boundaries of the State were expanded both within and outside the Swat valley. Outside the valley the territories of Buner, Khudu Khel, Shanglapar and the right-bank Indus Kohistan were occupied. However, although part of Swat Valley, both the right- and left-bank portions southwestward beyond Landakay were not incorporated in the State: the left-bank lower portion being incorporated in the Protected Area of the Agency of Dir and Swat (to which Chitral was added later on) after the Chitral expedition of 1895 and the right-bank lower part of the valley permanently went to the Nawab of Dir in 1922. The Torwali tract of Swat Kohistan was also incorporated in the State but the Kalam tract remained independent owing to the policy of the paramount authorities of India and later Pakistan - save the period from 14-15 August 1947 till 12 February 1954. The Pakistani authorities, however, considered the occupation for the said period too as unauthorised. On 12 December 1949, Miangul Abdul Wadud abdicated in favour of his son and heir apparent Miangul Jahanzeb with which Jahanzeb became the next ruler and ruled till the State's merger in Pakistan in $1969 .^{5}$

After the merger, the former State's areas and Kalam were made Swat District. In the Interim Constitution 1972 of Pakistan, the Provincially Administered Tribal Areas (PATA) were created and the then Swat District or the former Swat State areas and Kalam were made its part - the status, being retained in the Constitution of 1973, exist till now. Besides, the Indus Kohistan portion of Swat State and then Swat District was separated under the Constitution Sixth Amendment Bill 1976, with effect from 1 October 1976, and was made part of the newly created Kohistan District. The districts of Buner

and Shangla were also created in 1991 and 1995 respectively out of the then Swat District and formerly Swat State areas. In spite of separation of the aforesaid areas from the Swat District, all the areas that remained part of Swat State remain part of PATA.

This paper deals with the women's right to land ownership in the areas that comprised the former Swat State, and Kalam both in the State and post- State periods.

\section{The Swat State Era}

The sixteenth century proved turning point in the history of Swat and the adjoining areas, as the Yusufzai Afghans occupied the land, not only from political standpoint but also from the perspective of land ownership, because the land not only remained the basis of subsistence and prosperity in the agrarian and tribal society of the said areas but also "the main source of economic and political power" (Fredrik Barth, 1959) and "the vehicle of a political identity and involvement" (Michael E. Meeker, Dec.1980). 
In the traditional society riwaj (customary law) was the rule in respect of land ownership in Swat proper, Swat Kohistan, Buner, Shangla, Khudu Khel and Indus Kohistan portion of Swat State - the areas covered by this study - under which, as a rule, only the males could own and inherit land and the womenfolk held no right to own and inherit land. The land passed only to the patrilineal male heirs or the near agnates in case of having no male descendant. ${ }^{6}$ The Islamic right of women to own and inherit land was, as a rule generally not recognized.

The traditional practice (riwaj) remained the law to inheritance and land ownership after the emergence of Swat State as well. ${ }^{7}$ Miangul Abdul Wadud-commonly known and referred-to in Swat as Bacha Sahib-has claimed ${ }^{8}$ and Akbar S. Ahmed also reproduced that during his rule the "womenfolk were restored to their rightful place in society, and were given the rights and privileges expounded in the "Shariat" (Akbar S. Ahmed, 1976). In fact it was not so. Keeping aside other things and restricting to the subject matter of this paper the womenfolk's right to inherit and possess land has not been restored.

The Dir-Swat Land Disputes Enquiry Commission-constituted by the provincial government, after the merger of the State-has stated in some detail in its report that the rule of inheritance in Swat State was riwaj, according to which the female are not entitled to inherit. ${ }^{9}$ The Commission further states that Miangul Abdul Wadud himself told both in his oral and written statements to its members on 17 August 1971 that the rule of inheritance in Swat State "was Riwaj and not Shariat" hence the "women were not entitled to inherit property."

The very fact that Miangul Abdul Wadud himself made a will in 1939-attested by George Cunningum, the then Governor NWFP, and later by another governor of the province in 1949-wherein he bestowed his entire property only upon his two sons, shows that he "had no desire that Shariat should be followed [even] in relation to the question of his [own] inheritance."11 The Commission rightly observes that "if he had any intention of Shariat being followed, he would not have made a will at all, as it was unnecessary." 12

Not only the womenfolk were not entitled, as a rule, to inherit land in Swat State but there were restrictions upon them even in respect of the land given in mahar. Although they have to possess the land given in mahar, they were entitled to receive the produces only. They held no right to dispose-off the said land in any manner as selling and mortgaging was clearly forbidden to them. However, at the woman's death the said land went to her son and in case of having no son to the husband.13 Daughters are deprived here as well. 
The Dir-Swat Land Disputes Enquiry Commission, however, states that "though the general rule governing inheritance was Riwaj, it must be admitted that cases of disputed inheritance in which a party interested had to knock at the door of the State Judiciary, were referred to Qazis ${ }^{14}$ for decision according to Shariat." ${ }^{15}$ The Commission states that its members have seen a number of cases decided according to shariat and recorded in the concerned register. It refers to some cases of inheritance decided according to shariat in 1949, 1957, 1958 and 1961 and states that according to the "record the oldest case of inheritance decided on Shariat was recorded in 1937." 16 The Commission elsewhere states that between 1937 and 1949 some cases of inheritance were referred to the Qazis but generally decided by compromise. ${ }^{17}$

The Commission moreover states that it appears that the "practice of referring disputed cases of inheritance for decision according to Shariat was introduced by the present [sic, last] Wali [Miangul Jahanzeb] during his tenure of office as Wali and Wali Ahad"18 and that only the disputed cases of inheritance were referred to the Qazis after 1949 and decided by them according to shariat. ${ }^{19}$ But under Miangul Jahanzeb-commonly known and referred-to in Swat as Wali Sahib - too, at first, on the whole the situation remained the same. It was in 1960s that somewhat change took place and the Wali Sahib not only referred some of the disputed cases of inheritance to the Qazis "but in 1964 a separate register for recording of inheritance decisions on Shariat was started," ${ }^{20}$ for such cases decided by the Qazis in Mehkama Qaza. This register was called 'Ars Register'.

The State record, however, shows that the Wali Sahib did not refer all such cases to the Qazis. Not only he himself decided such cases without seeking opinion of the Qazis but his decisions and verdict, in this respect too, were not uniform. When the cases brought to or petitions filed before him in some cases he ordered giving not the whole shares but a portion. In some cases he gave some portion of the land to the females to the effect only to receive the produces for their sustenance and forbade its mortgaging and selling by them. He, thus, has given such verdicts or decided the cases, in both kinds of the verdicts, in clear compromising manner. ${ }^{21}$

In one of such orders, in the name of Mashir-e-Maal, the Wali Sahib states that Khairati of Kala Khela along with his stepmother appeared before me. In Khairati's produces of the land, the share to which the woman is entitled-to according to shariat, Khairati will give that shari share to her (Order sheet, 1967). In this order the Wali Sahib has termed the land as Khairati's ownership and decreed giving to the woman only the shari share in the produces. In an other order, on the application of a widow Khadam of Toor Warsak, the Wali Sahib stated that if the land's produces is up till six-eight maunds it will be in the woman and her daughter's hands as maintenance (nafqa), and if it gives ten or more than ten maunds produces her husband's brother will be given his shari share (Order of the Wali, 1968). In this order the widow and her daughter were granted the right of nafqa (maintenance), to the effect to receive the produces of the land to be sufficient for their 
maintenance. However, instead of their actual shari shares they were granted the right to receive all the produces in case these were too meagre.

In some cases the Wali Sahib decreed giving the whole shari shares - the shares entitledto according to Islamic law - to the females, imposing no restrictions over them not to dispose off the land. ${ }^{22}$ And in some cases he allowed giving the shari shares to the females, when his permission was sought for doing so, by the males who themselves wished to give the shari shares to their mothers, wives, sisters, and daughters, whatever the case was, or to distribute the land according to the Islamic law. ${ }^{23}$ In this category of cases some sought permission to divide or distribute the land in their lifetime per shares per Islamic law or to give share to their wives in their lifetime that is why wives are mentioned here in the preceding sentence.

The Wali Sahib, however, did not honour and implement Islamic law on the whole in this respect, which he himself admitted in his statement on 3 September 1971 before the members of the Dir-Swat Land Disputes Enquiry Commission by stating that he has never been able to enforce shariat as rule of inheritance generally. ${ }^{24}$ Besides, he did not issue a general order or decree to the effect to ask and order the people to use to give the females their due share in inheritance as he did in respect of various other issues and things. That was why during his reign too riwaj remained the core law and practice in respect of ownership and inheritance of land. This contention also got support from the fact that those who wished to give, on their own, the shari shares to the females concerned were required and hence has given applications for seeking special permission of the Wali, for doing so. ${ }^{25}$

There are instances that the Wali Sahib refused granting permission to the males, who sought his permission, to give to the females their share in inheritance. ${ }^{26}$ Therefore, the females were given or they received share in inheritance only in the cases where the Wali Sahib permitted or ordered. This speaks that, in general, as rule the Wali Sahib still considered the riwaj as the core law and rule in respect of inheritance and ownership of land due to which seeking his permission was required for those who wanted, on their own, to give the females their share, otherwise there was no need of his special permission. Therefore, the Dir-Swat Land Disputes Enquiry Commission rightly states that:

As already stated above and fully discussed in Chapter $\mathrm{V}$ of the main report, the general rule of inheritance in Swat and particularly in the family of the late Badshah Sahib [Miangul Abdul Wadud] is Riwaj. This is confirmed by some knowledgeable members of the public and some former State officials. [And] according to Riwaj women are not entitled to inheritance. $^{27}$ 
The Commission further states that "our general enquiry also shows" that inheritance in Swat State "was according to Riwaj and not Shariat. There may have been some few instances of women having been given a share in the property, but such cases were based on active volition and not on Shariat," 28 and that:

The rule of inheritance in the defunct State of Swat was and in the District of Swat still is Riwaj and not Shariat, though, as already stated, there have been a few exceptions to this rule in the former State. ${ }^{29}$

Like his father, the Bacha Sahib, the Wali Sahib too had no intention to follow the Islamic law in his own respect as rule to the inheritance of his father due to which he along with his brother made a joint statement later on 10 February 1972 that "we, the two brothers Miangul Jahanzeb and Sultan Room divide the whole property, moveable and immoveable of our late father...., half and half according to Riwaj of the land and wishes of our late father." ${ }^{30} \mathrm{He}$ thus denied his sisters their share per shariat despite his earlier appearance to be willing to give the sisters one-third of all his father properties with exception to those of some specified areas but that too "simply as a gift." 31

\section{The Post-State Scenario}

Swat State was brought to an end in 1969, but the rules, laws, and riwaj of the State were kept continued under section 7 of Regulation I of 1969, which run thus:

Continuance of Laws.-Subject to this Regulation, all laws, including Regulations, Orders, rules, notifications and customs having the force of law, with respect to any matter within the legislative competence of the Provincial Legislature, as were in force in the specified territories [i.e. the areas of the former states of Dir, Chitral and Swat] or any part thereof, immediately before the commencement of this Regulation, shall, so far as applicable, continue in force, until altered, repealed or amended by the competent authority (The All Pakistan Legal Decisions, 1970).

In this way, Swat State's rules and riwaj were retained also in respect of the land ownership and inheritance.

The Dir-Swat Land Disputes Enquiry Commission has stated in 1972 that "after the merger of the State the Settled District law of inheritance has not been extended to Swat, so that Riwaj is still being followed," 32 and that "even now, we [the Commission members] understand, in the Swat District inheritance cases are decided according to Riwaj and only those cases are referred to Qazis for Shariat decision where the parties concerned agree to decision by Shariat." 33 Hence, like Miangul Jahanzeb's reign, in the post-State period too there was neither, generally, a rule granting the womenfolk their 
share in inheritance nor uniform verdicts of the courts in disputed cases brought to the courts in respect of the females' right to the land in inheritance. In most of the cases the right has not been given, however.

On 15 January 1976, The West Pakistan Muslim Personal Law (Shariat) Application Act, 1962 (W.P. Act V of 1962), with exception to the proviso of sections 3 and 7, was extended to the then Swat District under the Provincially Administered Tribal Areas (Application of Laws) Regulation, 1975 (NWFP Regulation I of 1976) (See Ishfaq Ali) which granted the right of inheritance to the females. However, section 6 of the said Act prohibits its "retrospective operation" save as expressly provided by the provisions of sections 3, 4, and 5 (See section 6 of the W.P. Act V of 1962, 1999).

Application of The West Pakistan Muslim Personal Law (Shariat) Application Act, 1962 (W.P. Act V of 1962) to Swat District brought no practical change for the time being but the extension of this Act along with the land settlement carried out by the Provincial Revenue Department, in 1970s and 1980s, were destined to bring the change. Although both in the courts and practice riwaj was still adhered-to generally and in common, in the revenue entries names of the females are now also required to be entered when land is transferred in the names of the legal heirs in the revenue record. ${ }^{34}$ Now, it requires of the male heirs of a deceased, if they wish to enter all the land in their own names, to produce the female heirs before the Patwari or the court that they do not want to receive their legal share in the inheritance and hence has no objection of its entry in the names of the male heirs only.

Before the promulgation or enforcement of the Provincially Administered Tribal Areas (Nifaz-e-Nizam-e-Shariah) Regulation, 1994 (NWFP Regulation II of 1994), the Islamisation of laws was already started in Pakistan, which influenced or fascinated the judges of the higher courts. Special protection is, therefore, provided to the rights of the females by the superior judiciary, i.e. Supreme Court and High Courts. A landmark in this respect however is the verdict of the Supreme Court of Pakistan, given in 1990, in which it has been held that the females will not be deprived of their share in inheritance (For detail see PLD, Vol. 42 1990). The Supreme Court, however, has held the view and given the verdict in case of deprivation of the females by the male agnates without taking their consent for doing so. It does not bar the females from bestowing their share upon or giving up their share in favor of the male agnates; the social constraints in such cases, nevertheless, are referred to by the Supreme Court.The Supreme Court, moreover, not only held the view that deprivation of females from inheritance is against the public policy, but also enjoined upon the judiciary that:

The scope of rights of inheritance of females (daughter in this case [the case in which the decision is given]) is so wide and their thrust so strong that it is the duty of the Courts to protect and enforce them, even if the 
legislative action for this purpose of protection in accordance with Islamic Jurisprudence, is yet to take its own time [italics mine] (For detail see PLD, Vol. 42 1990).

The said verdict of the Supreme Court, however, was given under Chief Justice, Justice Muhammad Afzal Zullah, who, having no male issue, has two daughters only.

The Supreme Court also held the view that if the females are purdah observing (purdah nashin) and or illiterate and a deal is made on the basis of a deed on their part only this claim is sufficient on their part that we are purdah observing and illiterate therefore despite registered document or deed from their side in favour of males the burden of proof will lie on the beneficiary of the said deed. ${ }^{35}$

As all the courts in Pakistan are legally bound to obey the dictum of the Supreme Court, under articles 189 and 190 of the Constitution of $1973,{ }^{36}$ no court can pass a decree against the judgment of the Supreme Court in cases of the females' share in inheritance. Taking a serious notice of the tendency of ignoring its verdicts by the subordinate courts, the Supreme Court not only "stressed the need of following the principle of law enunciated by Supreme Court" but also "warned the Courts that serious view of the matter could be taken against the delinquent as and when the misconduct came or brought to the notice of the Supreme Court" (PLD, Vol. 46 (1994).

Nevertheless, before 12 February 1994 the executive officers were working as judicial officers in respect of civil rights. Despite the fact that the same was required of the executive officers as well, under the aforesaid article 190 of the Constitution of 1973, they did not care, as compared to the judicial officers, of the decisions made and verdicts passed by the superior courts. As they were not from the judiciary but belonged to the civil services cadre, they did not behave in the manner required of them under the law, as also been noted by the Supreme Court by stating that "experience shows the tendency on the part of Magistrates/Assistant Commissioners/Additional District Judges/District Judges to ignore the judgements of the superior Courts when cited before them" (PLD, Vol. 46 (1994).

When the Supreme Court declared the PATA Regulations (NWFP Regulations I and II of 1975) unconstitutional, (For detail see PLD, (1995) all the civil cases pending in the courts of the executive officers under the now defunct PATA Regulations were transferred to the regular courts, who were bound constitutionally as well as traditionally to follow the judgements of the Supreme Court and High Court. Moreover, as stated above, warning has been given to the judicial officers of the subordinate courts that in case of ignoring the decision of the Supreme Court, if brought in the notice of the Supreme Court, the contempt proceedings will be initiated against them (See PLD, Vol. 46 (1994). All the subordinate courts are therefore compelled to follow the decisions and 
verdicts of the superior courts in respect of the shari share of the females in the cases of inheritance. Besides, when the agitation for the implementation of the Islamic laws was started in the areas of the former Malakand Division and Kohistan District, the judicial officers became alarmed lest un-Islamic verdicts shall create problems; they started to follow Islamic laws while deciding the cases of inheritance.

The Provincially Administered Tribal Areas (Nifaz-e-Nizam-e-Shariah) Regulation, 1994 (NWFP Regulation II of 1994) and also the Kohistan District (Nifaz-e-Nizam-e-Shariah) Regulation, 1995 (Regulation I of 1995), commonly called the Sharia Regulation, and The Shari-Nizam-e-Adl Regulation, 1999 (NWFP Regulation I of 1999), which also was promulgated for the Tribal Areas in Kohistan District, are basically or mainly procedural laws, meaning they deal with the procedures of the courts. There, however, are also some substantive rights in every procedural law and the same is the case here in the case of the aforesaid Regulations.

Under section 11 (1) of the Provincially Administered Tribal Areas (Nifaz-e-Nizam-eShariah) Regulation, 1994 (NWFP Regulation II of 1994), The Provincially Administered Tribal Areas Criminal Law (Special Provisions) Regulation, 1975 (NWFP Regulation I of 1975), and the Provincially Administered Tribal Areas Civil Procedure (Special Provisions) Regulation, 1975 (NWFP Regulation II of 1975) - commonly called and referred-to collectively as PATA Regulations-were repealed. The Provincially Administered Tribal Areas (Nifaz-e-Nizam-e-Shariah) Regulation, 1994, was also enforced in the Kohistan District vide N.W.F.P. Regulation No I of 1995. Although the PATA Regulations were repealed, twenty-three such other Ordinances and Acts (given in Schedule I of the Regulation) were extended to and enforced in the area under the Provincially Administered Tribal Areas (Nifaz-e-Nizam-e-Shariah) Regulation, 1994 which were already enforced in the settled districts of the province. Nevertheless, section 11 (2) provided protection to all done under the previous rules, laws, and riwaj etc. by stating that:

(2) Notwithstanding the repeal of laws under subsection (1) of this section or cessation of any law, instrument, custom or usage under section 4, the repeal or cessation, as the case may be, shall not ---

(a) revive anything not in force or existing at the time at which the repeal or cessation takes effect;

(b) affect the previous operation of the law, instrument, custom or usage or anything duly done or suffered there under;

(c) affect any right, privilege, obligation or liability acquired, accrued or incurred under the law, instrument, custom or usage; . . . (Ali, p26) 
The Shari-Nizam-e-Adl Regulation, 1999, repealed the Provincially Administered Tribal Areas (Nifaz-e-Nizam-e-Shariah) Regulation, 1994 which was also extended to and enforced in the Kohistan District, under paragraph 12 (1). Besides, the Regulation extended and enforced twenty-nine such Acts and Ordinances (given in Schedule I of the Regulation), which were already in force in the settled areas of the province, and most of them were already extended and enforced under the now defunct Nifaz-e-Nizam-eShariah Regulation, 1990. However, paragraph 12 (2) provides protection to all done under the previous rules and laws etc. by stating that:

(2) Notwithstanding the repeal of the Regulation under sub-paragraph

(1) or cessation of any law, instrument, custom or usage under section 4, the repeal or cessation, as the case may be, shall not ---

(a) revive anything not in force or existing at the time at which the repeal or cessation takes effect;

(b) affect the previous operation of the law, instrument, custom or usage or anything duly done or suffered there under;

(c) affect any right, privilege, obligation or liability acquired, accrued or incurred under the law, instrument, custom or usage; ....(Ali, p47)

These, in other words, provides protection to the former riwaj and Swat State's rules in respect of inheritance and females' share in the land ownership to the effect of the previous operation and hence claims about the former times and generations or seeking and demanding shares on the basis of mothers' and grandmothers' shares are not to be entertained. The same has also been recognised and endorsed by the Peshawar High Court in 1984, on the basis of clause 6 of The West Pakistan Muslim Personal Law (Shariat) Application Act, 1962 (For detail see PLD, Vol. 36 (1984). In actual practice, the courts, however, entertained such petitions and cases which was contrary to the contents and spirits of the now defunct Provincially Administered Tribal Areas (Nifaz-eNizam-e-Shariah) Regulation, 1994, and are still entertaining such petitions and cases which is contrary to the contents and spirits of The Shari-Nizam-e-Adl Regulation, 1999, and also to clause 6 of The West Pakistan Muslim Personal Law (Shariat) Application Act, 1962.

The contrasting and conflicting conduct of the judiciary, to the extent of honouring and entertaining the cases regarding inheritance that belong to the former generations or are contested on the ground of seeking and demanding the shares of mothers and grandmothers, who died when Islamic law or more specific Islamic law of inheritance was not law of the land, with the purports and spirit of both clause 6 of The West Pakistan Muslim Personal Law (Shariat) Application Act, 1962 and The Shari-Nizam-eAdl Regulation, 1999, however, still remains. 
In spite of the separation of the right-bank Indus Kohistan portion and the Buner and Shangla districts from the Swat District, in 1976, 1991 and 1995 respectively, the legal position and status remained the same as detailed above and is still so in all the areas that remained part of Swat State, and Kalam.

\section{Conclusion}

Like the pre-State era, in Swat State customary law (riwaj) remained the rule and law to land ownership under which the women's were not entitled to inherit and own land, as a rule. The process of change started in 1960s at least in the disputed cases of inheritance brought to the Wali Sahib. Although the Wali Sahib's policy and conduct was not uniform and consistent, he took the first step in the right direction by granting inheritance right to the womenfolk in some cases, in a society in which it was though theoretically recognised but, in general, not in practice. The Wali Sahib's step of granting inheritance right to the womenfolk in selected cases too was, therefore, a milestone in this respect.

In the post-merger period, the situation remained the same as in 1960s under the Wali Sahib. The land settlement on modern lines, carried out from 1974 till 1986 in most parts of the area, and the extension of The West Pakistan Muslim Personal Law Shariat Application Act, 1962, on 15 January 1976, also proved landmarks in this regard. The verdict of the Supreme Court in 1990 along with its declaring the PATA Regulations null and void in 1994 proved another milestone.

There is the anomaly of the contrast between the law and the judiciary's conduct in respect of the disputed cases of inheritance dealing with the pre-1976 period and also of yet not having been a general implementation of the law; a gradual and evolutionary change is taking place not only due to the extension of the statutory law to the land and the courts' conduct but also due to the spread of both modern and religious education.

\section{End Notes:}

1 Jargah/Jirga/Jarga. Jargah means consultative assembly, forum, council, and council of the tribal chiefs. It has also other meanings, composition, functions and uses in different contexts.

2 For detailed description and analyses of the points dealt with in this paragraph see Sultan-i-Rome, "Swat State under the Walis (1917-69)" (Ph.D. dissertation, Department of History, University of Peshawar, 2000), chaps. 2-3; idem, Swat State (1915-1969): From Genesis to Merger (Karachi: Oxford University Press, 2007), chaps. 3-4; and for a summarized version see idem, Forestry in the Princely State of Swat and Kalam (North-West Pakistan): A Historical Perspective on Norms and Practices, IP6, Working Paper No. 6 (Swiss National Centre of Competence in Research (NCCR) North-South, 2005), chap. 2. 
3 For a comprehensive account of Miangul Abdul Wadud's life and career see Sultan-iRome, "Miangul Abdul Wadud" in Celebrities of NWFP, Vols. 1\&2 (Peshawar: Pakistan Study Centre, 2005), pp. 69-93.

4 For some detail about Abdul Ghafur alias Saidu Baba see Sultan-i-Rome, "Abdul Ghaffur (Akhund), Saidu Baba of Swat: Life, Career and Role, Journal of the Pakistan Historical Society (Karachi), Vol. 40 (July 1992), pp.

5 For detailed description and analyses of the points dealt with in this paragraph see Sultan-i-Rome, "Swat State under the Walis (1917-69)," chaps. 4-6, 9; idem, Swat State (1915-1969): From Genesis to Merger, chaps. 5-7, 10; and for a summarized version see idem, Forestry in the Princely State of Swat and Kalam (North-West Pakistan): A Historical Perspective on Norms and Practices, chap. 2.

6 Also see Fredrik Barth, Features of Person and Society in Swat: Collected Essays on Pathans, Selected Essays of Fredrik Barth, Vol. 2, ed. Adam Kuper (London: Routledge \& Kegan Paul Ltd., 1981), p. 66; idem, "Segmentary Opposition and the Theory of Games: A Study of Pathan Organization," The Journal of the Royal Anthropological Institute of Great Britain and Ireland (London), Vol. 89 (1959), p. 11; idem, Political Leadership among Swat Pathans, pp. 40, 74, 125; Makhdum Tasadduq Ahmad, Social Organization of Yusufzai Swat: A Study in Social Change (Lahore: Punjab University Press, 1962), p. 37; Sultan-i-Rome, "Saidu Baba and the Spread of Islam," The Frontier Post (Peshawar, 15 July 1988), Weekend Post, p. 4; idem, "Abdul Ghaffur (Akhund) Saidu Baba of Swat: Life, Career and Role," Journal of the Pakistan Historical Society (Karachi), Vol. 40 (July 1992), pp. 301, 307 n. 39.

7 Supplementary Report of Dir-Sawat Land Disputes Enquiry Commission, Part II, (Sawat), Vol.3 (Peshawar: Govt. of NWFP, Home, Tribal Affairs and Local Government Department, n.d.), p2.

8 Muhammad Asif Khan, The Story of Swat as Told by the Founder Miangul Abdul Wadud Badshah Sahib to Muhammad Asif Khan, [Preface, Introduction and Appendices by Muhammad Asif Khan; and trans. Preface and trans. by Ashruf Altaf Husain] (Printed by: Ferozsons Ltd., Peshawar, 1963), p. 115; idem, Tarikh Riyasat-eSwat wa Sawanih Hayat Bani Riyasat-e-Swat Hazrat Miangul Gul Shahzada Abdul Wadud Khan Bacha Sahib (Pukhtu), ["Dibbacha, Hisa Awal, and Hisa Swam" by Muhammad Asif Khan] (Printed by: Ferozsons Ltd., Peshawar, [1958]), p. 353.

9 See Report of Dir-Swat Land Disputes Enquiry Commission, Part II, Swat, Vol. 1,(Peshawar: Govt. of NWFP, Home, Tribal Affairs and Local Government Department, n.d.),pp. 46-47.

${ }^{10}$ ibid., p.46. 
11 Supplementary Report of Dir-Swat Land Disputes Enquiry Commission, Part II, (Swat), Vol. 3, p. 3. For the 'will' see ibid., p.6. Also see Report of Dir-Swat Land Disputes Enquiry Commission, Part II, Swat, Vol. 1, pp. 45-46.

12 Supplementary Report of Dir-Swat Land Disputes Enquiry Commission, Part II, (Swat), Vol. 3, p. 3. Also see Report of Dir-Swat Land Disputes Enquiry Commission, Part II, Swat, Vol. 1, pp. 47.

13 For example see Dastur-ul-Amal Aba Khel, 24 April 1939; Dastur-ul-Amal Barat khel, 24 April.1939, in District Record Room, Gulkada, Swat [hence forward DRRGS], Bundle No. nil, File No. nil, and Personal Collection of the Author [henceforward $P C A]$.

14 Qazi means a judge and a magistrate but in the case of Swat State status and position of the Qazi may not be taken in the sense attached with the words judge and magistrate.

15 Report of Dir-Swat Land Disputes Enquiry Commission, Part II, (Swat),Vol.1, p.47.

16 ibid.

17 Supplementary Report of Dir-Swat Land Disputes Enquiry Commission, Part II, (Sawat),Vol.3, p.3.

18 Report of Dir-Swat Land Disputes Enquiry Commission, Part II, (Swat),Vol.1, p.47.

19 Supplementary Report of Dir-Swat Land Disputes Enquiry Commission, Part II,(Sawat),Vol. 3. p.3.

${ }^{20}$ Report of Dir-SawatLand Disputes Enquiry Commission, Part II, Vol.1, p.47.

${ }^{21}$ For example see No. 88 (dated 11 June 1962) in "Kitab No. 3: Register Faisala Jat Daftar-e-Hizur, Az 16-9-58 Ta 4-8-69"; No. 180 (dated 6 April 1962) and No. 332 (dated 17 April 1963) in "Kitab No. 4: Ahkamat Daftar-e-Hizur Hukamran-e-Swat"; No. 174 (dated 7 July 1965) in "Register No. 73: Register Faisala Jat/Iqrarnama Jat, Az 29-8-62 Ta 30-10-68," DRRGS.

${ }^{22}$ For example see No. 118 (dated 25 January 1961), No. 163 (dated 16 December 1961) and No. 309 (dated 7 November 1962) in "Kitab No. 4: Ahkamat Daftar-e-Hizur Hukamran-e-Swat"; No. 174 (dated 17 August 1967) in "Kitab No. 8: Front Cover: Kitab Indiraj Mukhtalif Khatam Shudah, Faisala Jat Az Safha No. 1 Ta Safha No. 347, Kitab Daftar Sher Bahadar Khan Mashir Sahib; Back Cover: Kitab Wazir-e-Mulk Sahib, Faisala Jat, Maurkha 28-9-60 Ta 8-8-70"; No. 3 (dated 29 August 1962) in 
"Register No. 73: Register Faisala Jat/Iqrarnama Jat, Az 29-8-62 Ta 30-10-68," $D R R G S$. For some orders enjoining division of the sum received at the death of a deceased as inheritance among both the male and female heirs in accordance with shariat see No. 38 (dated 14 March 1966) in "Register No. 2: Qism Register, Zamanat Daftar-e-Hizur, Az 8-11-65 Ta 12-8-69”; No. 78 (dated 15 November 1961), No. 156 (dated 13 September 1967) in Kitab No. 3: Register Faisala Jat Daftar-e-Hizur, Az 169-58 Ta 4-8-69, DRRGS.For example see applications of Toor of Abuha (dated 10 January 1960), Nawab of Gogdara (dated 19 June 1961), Abdul Qahar of Mingawara (dated 31 March 1962), Muhammad Hanifa of Mingawara (dated 22 August 1966) and Arabi of Kokarai (dated 8 April 1967) and the orders of the Wali Sahib thereupon, PCA. Also see No. 8 (dated 9 September 1962) and No. 203 (dated 4 February 1966) in "Register No. 73: Register Faisala Jat/Iqrarnama Jat, Az 29-8-62 Ta 30-10-68, DRUGS.

23 For example see applications of Toor of Abuha (dated 10 January 1960), Nawab of Gogdara (dated 19 June 1961), Abdul Qahar of Mingawara (dated 31 March 1962), Muhammad Hanifa of Mingawara (dates 22 August 1966) and Arabi of Kokarai (dated 8 April 1967) and the orders of the Wali Sahib there upon, PCA. Also see No.8 (dated 9 September 1962) and No.203 (dated 4 February 1966) in "Register Faisala Jat/Iqrarnama Jat, Az 29-8-62 Ta 30-10-68,’ DRUGS.

${ }^{24}$ Report of Dir-Swat Land Disputes Enquiry Commission, Part II, Swat, Vol. 1, p. 47. Also see Supplementary Report of Dir-Swat Land Disputes Enquiry Commission, Part II, (Swat), Vol. 3, pp. 2-3.

25 The applications of Toor of Abuha (dated 10 January 1960), Nawab of Gogdara (dated 19 June 1961), Abdul Qahar of Mingawara (dated 31 March 1962), Muhammad Hanifa of Mingawara (dated 22 August 1966) and Arabi of Kokarai (dated 8 April 1967) and the orders of the Wali Sahib thereupon (in PCA) are clear proof on the subject.

26 Deduced from some of the interviews conducted and information sought by the author from oral sources.

27 Supplementary Report of Dir-Swat Land Disputes Enquiry Commission, Part II, (Swat),Vol.3, p.3. For details see Report of Dir-Sawat Land Disputes Enquiry Commission, Part II, Sawat, Vol.1, pp,45-47.

28 Report Dir-Sawat Land Enquiry Commission, Part II, Sawat, Vol. 1., p.46.

29 Supplementary Report of Dir-Swat Land Disputes Enquiry Commission, Part II, (Swat), Vol.3, pp.3-4. 
30 “Appendix 'B'," ibid., p.7.

${ }^{31}$ See ibid., p.3.

32 Supplementary Report of Dir-Swat Land Disputes Enquiry Commission, Part II, (Swat), Vol.3, p.2.

33 ibid., p.4.

34 The entries made and carried out in the revenue record at the time of the land settlement are called 'settlement entries' and the entries or changes made in the revenue record after the completion of the settlement are known as 'revenue entries'.

35 See Supreme Court Monthly Review [SMCR] (2001), Supreme Court of Pakistan, p. 1591; Pakistan Law Journal [PLJ], Vol. 33 (2005), Lahore, pp. 580-85.

${ }^{36}$ See Articles 189 and 190 in Muhammad Munir, Constitution of the Islamic Republic of Pakistan: Being a Commentary on the Constitution of Pakistan, 1973, ed. by Mian Bashir Ahmad, Vol. 2 [Art. 185-to Subject Index] (Lahore: PLD Publishers, 1996), pp. 873,881 .

\section{References:}

Ahmed, Akbar S. (1976) Millennium and Charisma among Pathans: A Critical Essay in Social Anthropology London: Routledge and Kegan Paul, p 125.

Ali, Ishfaq, Laws Extended to the Tribal Areas with Jirga Laws, second, revised and enlarged edition (Peshawar: New Fine Printers, n.d.), pp. 26. p.47, 7, 3, 262-264

For detail see PLD, Vol. 36 (1984), Peshawar, pp. 117-21.

For detail see PLD, (1995) Vol. 47, Supreme Court, pp. 281-306.

For detail see PLD, Vol. 42 (1990), Supreme Court, pp. 8-27, 26

Fredrik, Barth. Political Leadership among Swat Pathans (London: The Athlone Press, 1959 , p. 24

Imperial Gazetteer of India, Provincial Series, North-West Frontier Province, reprint (Lahore: Sang-e-Meel Publications, 1991), p. 216.

Michael E, Meeker. The Twilight of a South Asian Heroic Age: A Rereading of Barth's Study of Swat, Man (London), Vol. 15 (December 1980), p. 692. 
Order sheet of the Wali's order in respect of Kairati of Kala Khela and his Stepmother, dated 26 September 1967, $P C A$.

Order of the Wali on the application of Khadam of Toor Warsak, dated 20 February 1968, ibid.

PLD, Vol. 46 (1994), Supreme Court, p. 881.

Section 6 of the W.P. Act V of 1962, in M. Hakim Amir Bakhsh Awan, Comprehensive Manual of Family Laws in Pakistan (Lahore: Comprehensive Publishers, 1999), p. 636.

The All Pakistan Legal Decisions [PLD], Vol. 22 (1970), West Pakistan Statutes, p. 2.

Dr. Sultan-i-Rome is Assistant Professor of History at Government College Matta, Swat, Pakistan. He has written extensively on a variety of aspects of the Swat Valley. His papers have been published in peer-reviewed journals, books and conference proceedings. This paper is an enlarged version of some sections of the author's doctorate dissertation. 